\title{
Chapter 2 \\ What Is Citizen Science? The Challenges of Definition
}

\author{
Mordechai (Muki) Haklay, Daniel Dörler, Florian Heigl, Marina Manzoni, \\ Susanne Hecker, and Katrin Vohland
}

\begin{abstract}
In this chapter, we address the perennial question of what is citizen science? by asking the related question, why is it challenging to define citizen science? Over the past decade and a half, we have seen the emergence of typologies, definitions, and criteria for qualifying citizen science. Yet, citizen science as a field seems somewhat resistant to obeying a limited set of definitions and instead attracts discussions about what type of activities and practices should be included in it. We explore how citizen science has been defined differently, depending on the context. We do that from a particularly European perspective, where the variety of national and subnational structures has also led to a diversity of practices. Based on this background, we track trade-offs linked to the prioritisation of these different objectives and aims of citizen science. Understanding these differences and their origin is important for practitioners and policymakers. We pay attention to the need for definitions and criteria for specific contexts and how people in different roles can approach the issue of what is included in a specific interpretation of citizen science.
\end{abstract}

M. (M.) Haklay ( $ه)$

Extreme Citizen Science Research Group, University College London (UCL), London, UK

e-mail:m.haklay@ucl.ac.uk

D. Dörler · F. Heigl

Institute of Zoology, University of Natural Resources and Life Sciences, Vienna, Austria

M. Manzoni

European Commission Joint Research Centre (JRC), Ispra, Italy

S. Hecker

Museum für Naturkunde Berlin - Leibniz Institute for Evolution and Biodiversity Science (MfN), Berlin, Germany

Helmholtz Centre for Environmental Research - UFZ \& German Centre for Integrative Biodiversity Research (iDiv), Halle, Jena, Leipzig, Germany

K. Vohland

Museum für Naturkunde Berlin - Leibniz Institute for Evolution and Biodiversity Science (MfN), Berlin, Germany

Natural History Museum (NHM), Vienna, Austria

(C) The Author(s) 2021

K. Vohland et al. (eds.), The Science of Citizen Science, https://doi.org/10.1007/978-3-030-58278-4_2 
Keywords Citizen science terminology - Quality criteria - Cultural differences · Policy applications

\section{Introduction}

The first recorded use of the term citizen science in the form that we currently use can be traced to three decades ago, according to the researchers of the Oxford English Dictionary (OED). The term appeared in an issue of the MIT Technology Review from January 1989. The article 'Lab for the Environment' covers three examples: community-based laboratories that explore environmental hazards, laboratory work by Greenpeace, and Audubon's recruitment of volunteers in a 'citizen science' programme. With regard to the latter, it states: "'Speed is also crucial to the Audubon Society's acid-rain campaign. Government studies sometimes withhold data for years", says Audubon vice president Robert San George. Audubon involves 225 society members from all 50 states in a "citizen science" program that gets information out within five weeks. Volunteers collect rain samples, test their acidity levels, and report the results to Audubon headquarters, which releases a monthly national map of acidrain levels. The information is used to lobby Congress' (Kerson 1989, p. 12).

This origin story provides an indication of what citizen science is: it includes the generation of scientific data (through the testing of the acidity of rainwater), engages volunteers over a large area (the continental USA), and addresses a politically relevant issue (acid rain and the lobbying process to reduce it). Yet, as we look through a table of definitions of citizen science - which were taken from influential actors and documents (Table 2.1) - a pattern starts to emerge. While all these definitions have things in common - in particular, a notion of a public that participates in an activity called scientific research - most of them are imprecise and open to interpretation. We will come back to look at these definitions, but, as a starting point, we should recognise that there is an inherent challenge in providing an exhaustive definition of citizen science encompassing the many different purposes and approaches applied to even more diversified contexts. It is important for practitioners and policymakers to understand these differences so that they can navigate and support the full breadth of opportunities available in and through citizen science.

From the collection in Table 2.1, it is clear that a definition of citizen science includes an instrumental side: it must reflect the objectives of the actors and the extent of the engagement of citizens in the different processes generating scientific knowledge. This means that citizen science (and its definitions) needs to encompass and promote an open and broad understanding of manifold research practices and participatory activities that can take place when people, who are not tasked with carrying out research as part of their paid work, get involved in research. This multiplicity of definitions is essential to the development of citizen science - its enabling frameworks and mechanisms and the different needs of specific fields of application. For example, when applying for European Union (EU) funding for a citizen science project, the White Paper on Citizen Science for Europe (Serrano Sanz et al. 2014) definition might be the best one to use. Alternatively, when addressing 
Table 2.1 Selected definitions of citizen science

\begin{tabular}{|c|c|c|}
\hline 1 & Oxford English Dictionary (2014) & $\begin{array}{l}\text { Scientific work undertaken by members of the gen- } \\
\text { eral public often in collaboration with or under the } \\
\text { direction of professional scientists and scientific } \\
\text { institutions }\end{array}$ \\
\hline 2 & Wikipedia (2005) & $\begin{array}{l}\text { A project (or ongoing program of work) which aims } \\
\text { to make scientific discoveries or verify scientific } \\
\text { hypotheses }\end{array}$ \\
\hline 3 & Wikipedia (2019) & $\begin{array}{l}\text { Scientific research conducted, in whole or in part, by } \\
\text { amateur (or nonprofessional) scientists }\end{array}$ \\
\hline 4 & National Geographic Encyclopedia & $\begin{array}{l}\text { Citizen science is the practice of public participation } \\
\text { and collaboration in scientific research to increase } \\
\text { scientific knowledge. Through citizen science, peo- } \\
\text { ple share and contribute to data monitoring and } \\
\text { collection programs }\end{array}$ \\
\hline 5 & $\begin{array}{l}\text { Australian Citizen Science } \\
\text { Association }\end{array}$ & $\begin{array}{l}\text { Citizen science involves public participation and } \\
\text { collaboration in scientific research with the aim to } \\
\text { increase scientific knowledge. It's a great way to } \\
\text { harness community skills and passion to fuel the } \\
\text { capacity of science to answer our questions about } \\
\text { the world and how it works }\end{array}$ \\
\hline 6 & $\begin{array}{l}\text { European Citizen Science } \\
\text { Association }\end{array}$ & $\begin{array}{l}\text { Citizen Science - the participation of the general } \\
\text { public in scientific processes... an open and inclu- } \\
\text { sive approach, for example, by supporting and being } \\
\text { part of the exploration, shaping, and development of } \\
\text { the different aspects of the citizen science move- } \\
\text { ment, its better understanding, and use for the ben- } \\
\text { efit of decision-making }\end{array}$ \\
\hline 7 & $\begin{array}{l}\text { European Citizen Science } \\
\text { Association }\end{array}$ & $\begin{array}{l}\text { Citizen science projects actively involve citizens in } \\
\text { scientific endeavour that generates new knowledge } \\
\text { or understanding }\end{array}$ \\
\hline 8 & Citizen Science Association (US) & $\begin{array}{l}\text { Citizen science is the involvement of the public in } \\
\text { scientific research, whether community-driven } \\
\text { research or global investigations }\end{array}$ \\
\hline 9 & $\begin{array}{l}\text { Group on Earth Observations Citizen } \\
\text { Science Working Group }\end{array}$ & $\begin{array}{l}\text { Citizen science encompasses a range of methodol- } \\
\text { ogies that encourage and support the contributions } \\
\text { of the public to the advancement of scientific and } \\
\text { engineering research and monitoring in ways that } \\
\text { may include co-identifying research questions; } \\
\text { co-designing/conducting investigations; } \\
\text { co-designing/building/testing low-cost sensors; } \\
\text { co-collecting and analysing data; co-developing } \\
\text { data applications; and collaboratively solving com- } \\
\text { plex problems }\end{array}$ \\
\hline 10 & $\begin{array}{l}\text { United Nations Environmental } \\
\text { Programme (UNEP) (2019) }\end{array}$ & $\begin{array}{l}\text { Citizen science entails the engagement of volunteers } \\
\text { in science and research. Volunteers are commonly } \\
\text { involved in data collection but can also be involved } \\
\text { in initiating questions, designing projects, dissemi- } \\
\text { nating results, and interpreting data }\end{array}$ \\
\hline
\end{tabular}


Table 2.1 (continued)

\begin{tabular}{|c|c|c|}
\hline 11 & UNESCO (2013) & $\begin{array}{l}\text { The participation of a range of non-scientific stake- } \\
\text { holders in the scientific process. At its most inclu- } \\
\text { sive and most innovative, citizen science involves } \\
\text { citizen volunteers as partners in the entire scientific } \\
\text { process, including determining research themes, } \\
\text { questions, methodologies, and means of dissemi- } \\
\text { nating results }\end{array}$ \\
\hline 12 & $\begin{array}{l}\text { US Crowdsourcing and Citizen Sci- } \\
\text { ence Act (15 USC 3724) (2016) }\end{array}$ & $\begin{array}{l}\text { The term citizen science means a form of open } \\
\text { collaboration in which individuals or organizations } \\
\text { participate in the scientific process in various ways, } \\
\text { including (A) enabling the formulation of research } \\
\text { questions; (B) creating and refining project design; } \\
\text { (C) conducting scientific experiments; } \\
\text { (D) collecting and analysing data; (E) interpreting } \\
\text { the results of data; (E) interpreting the results of } \\
\text { data; (F) developing techologies and applications; } \\
\text { (G) making discoveries; and (H) solving problems }\end{array}$ \\
\hline 13 & Citizenscience.gov (US) & $\begin{array}{l}\text { In citizen science, the public participates voluntarily } \\
\text { in the scientific process, addressing real-world } \\
\text { problems in ways that may include formulating } \\
\text { research questions, conducting scientific experi- } \\
\text { ments, collecting and analysing data, interpreting } \\
\text { results, making new discoveries, developing tech- } \\
\text { nologies and applications, and solving complex } \\
\text { problems }\end{array}$ \\
\hline 14 & US National Institutes of Health & $\begin{array}{l}\text { Citizen science efforts are driven by community } \\
\text { concerns. These community-led projects may } \\
\text { involve a partnership with an academic or research } \\
\text { institution, where both parties work together to col- } \\
\text { lect and share data. The goal is to address a com- } \\
\text { munity concern through collaborative research and } \\
\text { to translate the research findings into public health } \\
\text { action that benefits the community }\end{array}$ \\
\hline 15 & $\begin{array}{l}\text { US Environmental Protection } \\
\text { Agency (EPA) (2018) }\end{array}$ & $\begin{array}{l}\text { Citizen science is a form of open collaboration in } \\
\text { which individuals or organizations participate vol- } \\
\text { untarily in the scientific process in various ways, } \\
\text { including collecting and analysing data. Citizen } \\
\text { science provides a way for members of the public to } \\
\text { participate and support EPA programs }\end{array}$ \\
\hline 16 & $\begin{array}{l}\text { The US National Aeronautics and } \\
\text { Space Administration (NASA) }\end{array}$ & $\begin{array}{l}\text { Citizen science is defined as a form of open collab- } \\
\text { oration in which individuals or organizations par- } \\
\text { ticipate voluntarily in the scientific process in } \\
\text { various ways. This policy defines citizen science } \\
\text { projects as science projects that rely on volunteers }\end{array}$ \\
\hline 17 & $\begin{array}{l}\text { US National Oceanic and Atmo- } \\
\text { spheric Administration (NOAA) }\end{array}$ & $\begin{array}{l}\text { Citizen science is defined as a form of open collab- } \\
\text { oration where members of the public participate in } \\
\text { the scientific process to address real-world problems } \\
\text { in ways that include identifying research questions, } \\
\text { collecting and analysing data, interpreting results, } \\
\text { making new discoveries, developing technologies } \\
\text { and applications, and solving complex problems }\end{array}$ \\
\hline
\end{tabular}


Table 2.1 (continued)

\begin{tabular}{|c|c|c|}
\hline 18 & $\begin{array}{l}\text { The US National Academies of Sci- } \\
\text { ence (2018) }\end{array}$ & $\begin{array}{l}\text { The involvement of the broader public in the } \\
\text { research enterprise }\end{array}$ \\
\hline 19 & EC Environment (2013) & $\begin{array}{l}\text { Citizen science encompasses many different ways in } \\
\text { which citizens are involved in science. This may } \\
\text { include mass participation schemes in which citi- } \\
\text { zens use smartphone apps to submit wildlife moni- } \\
\text { toring data as well as smaller-scale activities }\end{array}$ \\
\hline 20 & Socientize (2014) & $\begin{array}{l}\text { Citizen science refers to the general public engage- } \\
\text { ment in scientific research activities when citizens } \\
\text { actively contribute to science either with their } \\
\text { intellectual effort or surrounding knowledge or with } \\
\text { their tools and resources }\end{array}$ \\
\hline 21 & EU (2016) & $\begin{array}{l}\text { Inclusion of non-institutional participants, in other } \\
\text { words the general public, in the scientific process }\end{array}$ \\
\hline 22 & EU (2017) & $\begin{array}{l}\text { Citizen science - where citizens become providers } \\
\text { and users of data. This will reinforce and give new } \\
\text { meaning to the policy of open access to publications } \\
\text { and data; this openness should enable citizens and } \\
\text { citizen groups to participate in evidence-based pol- } \\
\text { icy and decision-making }\end{array}$ \\
\hline 23 & EU (2019) & $\begin{array}{l}\text { More and more Europeans hold higher education } \\
\text { degrees. Enabled by digitalisation and knowledge, } \\
\text { citizens are today prosumers capable of shaping the } \\
\text { innovation process and bypassing restrictive prac- } \\
\text { tices of established sectors and governments. This } \\
\text { goes well beyond citizen science and covers the } \\
\text { entire research and innovation process }\end{array}$ \\
\hline 24 & OSPP (2018) & $\begin{array}{l}\text { Broadly defined, citizen science is 'scientific work } \\
\text { undertaken by members of the general public, often } \\
\text { in collaboration with or under the direction of pro- } \\
\text { fessional scientists and scientific institutions'. Citi- } \\
\text { zen science is an already very diverse practice, } \\
\text { encompassing various forms, depths, and aims of } \\
\text { collaboration between academic and citizen } \\
\text { researchers and a broad range of scientific disci- } \\
\text { plines. Civic participation in research can range } \\
\text { from short-term data collection to intensive } \\
\text { involvement in the research process, from technical } \\
\text { contribution to genuine research, and from collabo- } \\
\text { ration to co-creation of knowledge. Yet, there is still } \\
\text { a need to define and establish citizen science as a } \\
\text { genuine, open research approach }\end{array}$ \\
\hline 25 & G7 Science Academies (2019) & $\begin{array}{l}\text {... Two categories of citizen science. The first one, } \\
\text { which is predominant, is participatory research done } \\
\text { by citizens who have not necessarily received } \\
\text { training in scientific research. It was this activity that } \\
\text { has been historically named 'citizen science'... A } \\
\text { second and more recent category of citizen science } \\
\text { involves scientifically trained individuals working } \\
\text { in isolation, or in virtual communities, to develop }\end{array}$ \\
\hline
\end{tabular}


Table 2.1 (continued)

\begin{tabular}{|c|c|c|}
\hline & & $\begin{array}{l}\text { projects outside established controlled environ- } \\
\text { ments (university, government, or industry research } \\
\text { system) }\end{array}$ \\
\hline 26 & OECD (2017) & $\begin{array}{l}\text { At the heart of the scientific process, it can be more } \\
\text { narrowly understood as people, who are not pro- } \\
\text { fessional scientists, taking part in research, } \\
\text { i.e. co-producing scientific knowledge. This } \\
\text { involves collaborations between the public and } \\
\text { researchers/institutes but also engages governments } \\
\text { and funding agencies }\end{array}$ \\
\hline 27 & Science Europe (2018) & $\begin{array}{l}\text { The practice of citizens performing science and of } \\
\text { scientists working together with citizens }\end{array}$ \\
\hline 28 & LERU (2016) & $\begin{array}{l}\text { Citizen science, the active involvement of } \\
\text { nonprofessional scientists in research... The bound- } \\
\text { aries of what can rightly be termed citizen science } \\
\text { are debatable, but there is broad consensus that } \\
\text { projects should involve voluntary and active public } \\
\text { engagement with research }\end{array}$ \\
\hline 29 & RAND Corporation (2017) & $\begin{array}{l}\text { Citizen science takes open science activities beyond } \\
\text { the purview of professional scientist circles by } \\
\text { exploring the involvement of citizens in scientific } \\
\text { research and the implications of these activities on } \\
\text { and within society }\end{array}$ \\
\hline 30 & $\begin{array}{l}\text { Green Paper Citizen Science Strat- } \\
\text { egy } 2020 \text { for Germany (2016) }\end{array}$ & $\begin{array}{l}\text { Citizen science describes the process of generating } \\
\text { knowledge through various participatory formats. } \\
\text { Participation can range from the short-term collec- } \\
\text { tion of data to the intensive use of leisure time to } \\
\text { delve deeper into a research topic together with } \\
\text { scientists and/or other volunteers, to ask questions, } \\
\text { and to get involved in some or all phases of the } \\
\text { research process }\end{array}$ \\
\hline 31 & $\begin{array}{l}\text { UK Parliamentary Office of Science } \\
\text { and Technology (POST) (2014) }\end{array}$ & $\begin{array}{l}\text { Environmental citizen science - the involvement of } \\
\text { volunteers in environmental monitoring }\end{array}$ \\
\hline 32 & $\begin{array}{l}\text { UK Environmental Observation } \\
\text { Framework (2012) }\end{array}$ & $\begin{array}{l}\text { Citizen science, broadly defined as the involvement } \\
\text { of volunteers in research }\end{array}$ \\
\hline 33 & Nesta (2019) & $\begin{array}{l}\text { Citizen science is any process where scientists and } \\
\text { the public process scientific data or observations. } \\
\text { Citizen science (usually unpaid) volunteers work } \\
\text { together to collect or unlock new resources for } \\
\text { research, experimentation, and analysis by opening } \\
\text { the process to everyone }\end{array}$ \\
\hline 34 & $\begin{array}{l}\text { Environmental Science \& Technol- } \\
\text { ogy journal (2007) }\end{array}$ & $\begin{array}{l}\text { According to Wikipedia, the term citizen science } \\
\text { refers to a program in which a network of volun- } \\
\text { teers, many of whom have little or no specific sci- } \\
\text { entific training, perform or manage research-related } \\
\text { tasks, such as observation, measurement, or } \\
\text { computation }\end{array}$ \\
\hline
\end{tabular}

For the sources of these definitions, please see the information on GitHub (Haklay et al. 2019) 
engagement in policy, the definition developed by the Open Science Policy Platform (OSPP - see Table 2.1) in 2018 could provide a good example. In short, fitness for purpose is an important aspect when choosing a definition to be used in a given context.

At the same time, the definitions also provide descriptive elements, outlining certain features of the research collaboration, which is especially clear in the case of the Oxford English Dictionary (2014), where the aim is to provide an explanation of the term, as well as in the case of Wikipedia. Finally, all the definitions also have a normative aspect. The normative aspect of the definitions lies in setting the expectations of the different actors within a citizen science project, for example, alignment with matters of concern (Liu and Kobernus 2017; Balestrini et al. 2015), legal alignment (Rogers 2010) and normative pressure (Venkatesh et al. 2003), and alignment to social norms (Venkatesh and Davis 2000; Fishbein and Ajzen 1975) and social factors (Thompson et al. 1991).

Our aim in this chapter is to explore the ambiguity of citizen science definitions, and, instead of narrowing it down by providing a set of criteria to frame citizen science, we want to explore what it tells us about the field and how it is articulated in different contexts under different conditions. This has important implications for those involved in doing citizen science. On the one hand, the lack of a concrete definition is a problem for people who are interested in learning about the field, providing policy support, or creating funding programmes. On the other hand, because the activities of citizen science cover a wide range of academic research fields - each with its own objectives, worldview, and approach to the construction of knowledge (what is known as epistemology), methodologies, and classification of the world (known as ontology) - a single or narrow definition would risk the exclusion of a variety of activities from citizen science. This is a concrete problem, since with the increasing availability of funding for citizen science projects, excluding an activity through a given definition can cause its exclusion from funding. Those applying for citizen science funding need to be aware of these differences for their applications to be successful. This can also create antagonism between different practitioners when engaging the public in research, therefore reducing the growth of citizen science in new areas of activities (amongst other things).

We also need to emphasise, from the start, the best practice principles that were established by the European Citizen Science Association (ECSA) to provide guidance on the fundamental principles and elements expected of a good citizen science project - these are widely known as the ECSA 10 Principles of Citizen Science. As Robinson et al. (2018) point out, there are many caveats to these principles, and they are not a replacement for a clearer articulation of citizen science in a form that fits into specific contexts and needs. We are therefore not aiming to replace or challenge these principles, rather to extend the discussion about the nuance which we need to consider when applying them.

This discussion, and the mapping approach, proposed later in this chapter, could also support the integration and, hopefully, mainstreaming of citizen science concepts and practices within the implementation of European and national research and innovation programmes. Furthermore, discussion and mapping could contribute to 


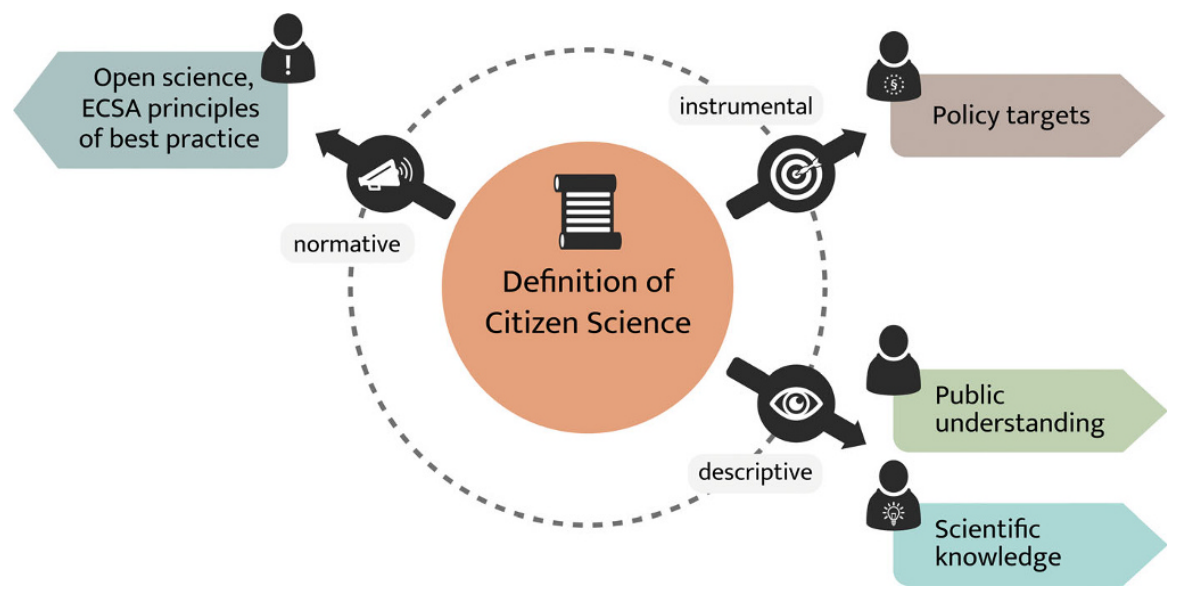

Fig. 2.1 Dimensions of definitions

deeper research in this field, enriching the evolution of citizen science understandings, definitions, and practices over the next decade in Europe.

We therefore try to demonstrate the complexities of defining citizen science while, at the same time, providing some directions and useful information that could help practitioners, scientists, and policymakers to make sense of the multiple approaches in citizen science and the factors that affect its relevant and effective application to the given contexts.

To achieve this, the chapter will cover four aspects. Since the origins and earlier examples of citizen science dated to the mid-1990s have been well rehearsed (e.g. Cooper and Lewenstein 2016), we turn to the challenges of definitions. Using the set of definitions presented in Table 2.1, we highlight some of the challenges and inconsistencies that these definitions reveal, as well as their instrumental, descriptive, and normative aspects (Fig. 2.1). Next, we show the variety of understandings of citizen science in various European countries and then pay special attention to the development of quality criteria for listing a project on the Austrian citizen science platform Österreich forscht as one of the first examples of articulating criteria for citizen science projects. In addition, the development of the criteria led to a noteworthy discussion within the citizen science practitioners' community. With these examples and context, we move to the final part of the chapter, in which we try to reconcile these apparent contradictions and challenges in a discussion that maps the roles and constraints of different actors and the way that they have developed (and will develop) criteria and definitions that are fit for their specific context, culture, and practice. 


\section{The Challenges and Dimensions of Definitions}

The overview of nearly 35 definitions in Table 2.1 - collected from multiple sources and originating from the efforts of Auerbach et al. (2019) - presents the range of definitions within the field of citizen science (see Haklay et al. 2019 for further details). The compilation is not a systematic collection of definitions, rather a curated list that covers different areas of the world, areas of policy, and a variety of sources most of them have either policy or practice impacts. They include definitions that were created by practitioner associations, within laws and regulations, in official reports that are aimed at policy impact, and in widely used references in the research field.

Our aim is not to carry out a full content analysis of the definitions - such an analysis of the term citizen science can be found in Hecker et al. (2019) - but to use this collection to examine some of the issues that emerge from even a cursory analysis of it. In particular, we will look at the descriptive, instrumental, and normative aspects of the different definitions. Following this examination, we look at what such aspects tell us about epistemology, methodology, and social practice and possible impacts on the given context of application.

The set of definitions is organised as follows: 1-4 are taken from reference sources; 5-8 are from citizen science associations; 9-11 are from global multinational organisations; 12-18 are from the USA where the Crowdsourcing and Citizen Science Act of 2016 (12) has impacted federal agencies (13-18); 19-24 are from the European Commission and its related bodies; 25-29 are from science-focused bodies; 30-32 provide national examples from Germany and the UK; and the list closes with Nesta, the influential UK innovation charity, and an early example of citizen science in an academic journal editorial in 2007.

All the definitions have a descriptive element - they are trying to describe the type of activity that is termed 'citizen science'. This is in particular the case for dictionaries and encyclopaedias (1-4). Note, for example, the more generic approach in definitions $1-3$, where the participation is in 'scientific work' (whatever that is), in comparison to the more environmentally focused definition from the National Geographic, where the work is 'data monitoring and collection'. This descriptive tension can also be noted across other definitions, such as the EU (19 and 22) definitions that focus on data collection practices, in comparison to the generic definitions in 21 and 24. Overall, the more generic and open definitions seem to be more common.

The definitions also have an instrumentalist aspect, which especially stands out in the case of US agencies' definitions (12-18) where the agencies adopt a version that matches their goals and objectives - notice how the US National Institutes of Health definition (14) is clearly linked to community-based participatory research, a longstanding focus of the US National Institute of Environmental Health Science. Another instrumentalist focus is about the expectations of the definition's writer (s) from citizen science - for example, the EU Lamy report (22) sees the value in participation in evidence-based policy and decision-making. 
Finally, across the definitions there are normative aspects of citizen science that are included - for example, the expectation that the participants are volunteers, which is noted in 11 definitions $(10,11,13,15,16,28,30,31,32,33$, and 34). However, the assumption about volunteering, in the sense of an unremunerated activity, as a prerequisite to participation is problematic when working with marginalised and socially disadvantaged groups, who might need to be compensated for the time that they are dedicating to the project, or when the project is community led and executed to support community aims. Indeed, the community-oriented definition of the US National Institutes of Health (14) does not mention volunteering. Another normative aspect is the role of citizen science within open science, such as in the RAND Corporation (29), where it is taking science beyond the control of professional scientists or opening science - which is also recognised by the G7 science academies (25). The G7 definition mentions that citizen science works outside the 'established controlled environment' of universities and research institutions. Thus, both the RAND and G7 definitions and documents point to the benefits but also the risks of research activities that are happening outside regular actors in the research process. There is also an indication of different levels of engagement - for example, the UNESCO definition (11) points to citizen science's potential as a most inclusive and innovative form of participating in science and is thus clearly elevating the value of such a deep engagement.

Beyond their descriptive, instrumental, and normative elements, the definitions also help demonstrate the deeper challenges of defining citizen science - these go to the heart of the philosophy of science. The practices that fall under the term citizen science cross many disciplinary boundaries in academia. While the world of research and science is divided between humanities, social sciences, and science, the participants might have multiple interests - a variety that is represented by the diversity of citizen science platforms. Thus, on the Zooniverse platform, we can find projects in all these areas. Indeed, when we look within scientific disciplines, we can find citizen science projects in physics, life science, medicine, ecology, biology, and many other fields. The modern research enterprise is structured around disciplines - from university departments to funders and to academic journals - all are geared towards specialisation in disciplines and subdisciplines, and activities that cross multiple disciplines (interdisciplinary activities) continue to require special support. This clash - between well-established academic structures and the practice of citizen science across research areas - is the source of a challenge in the definitions.

We can start by looking at the epistemological challenge. Citizen science is an activity that engages with the creation of new knowledge, and here the meaning of 'science' is significant. In some definitions, it is the natural and life sciences that are included, while in others this is a reference to modern academic research in all its varieties - including social sciences and the humanities. For example, the Wikipedia definition from 2005 (2) expresses an expectation that the project should lead to scientific discoveries or verify a hypothesis - the hallmark of the natural and life sciences. The use of science (without the wider concept of research) also appears in all the definitions that are used by citizen science associations (5-8). An alternative 
emphasis is offered by the US National Academies (18) which talk about a generic 'research enterprise', as well as LERU's (28) use of 'research'.

On the methodological side, there is the question of what activities we can expect the participants to carry out. Here, some definitions are geared more towards the dominant ecological observational understanding of citizen science as mostly a data collection activity - for example, definition 31 from the UK Parliamentary Office for Science and Technology. Similarly, the definition from an editorial in the Environmental Science \& Technology journal (34) also emphasises specific tasks - observation, measurement, and computation. Other definitions are aimed at a wider range of activities - here the Group on Earth Observations (9) and the Crowdsourcing and Citizen Science Act (12) are especially comprehensive in the list of tasks and activities - including collaborative solving of complex problems.

Finally, there is a social practice. When we looked at the normative aspect, we have noted the assumption that citizen science is a leisure activity and an expectation that the participants do not get any financial benefit from participation. Therefore, volunteerism is central to the understanding of citizen science. Other examples of social practices appear in definitions - for example, the linkage between citizen science and the research and innovation process. Definition 23, which comes from an EU document developing ideas for future research and innovation, suggests that there is a need to 'bypass restrictive practices of established sectors and governments'. Notice that this definition suggests that participation in the entire research and innovation process is 'beyond citizen science', thus revealing a restrictive conceptualisation of citizen science by the document authors as working within the boundaries of the established research system.

There are, of course, many other disagreements and inconsistencies within these definitions and beyond them, which the reader can use as a personal exercise (e.g. identifying ontological disagreements), but this is not the purpose of the analysis here. What we aimed to demonstrate is that defining citizen science is difficult, and it reveals as much of the author's or authors' perspectives, as it does about citizen science. We can now turn to look at the specific ways in which citizen science is understood across Europe.

\section{Different Interpretations of Citizen Science in Europe}

When we go beyond the collection of definitions, we can also observe different perceptions and foci, according to cultural differences and diversified contexts, in referring to and applying citizen science approaches, leading to the simultaneous use of different definitions.

For example, in Europe, according to the outcomes from a recent pan-European survey of citizen science strategies and practices in COST countries ${ }^{1}$ (carried out as

\footnotetext{
${ }^{1}$ More details in Vohland et al., this volume, Chap. 1
} 
part of COST Action CA15212 Citizen Science to Promote Creativity, Scientific Literacy, and Innovation throughout Europe, under Working Group 3 - Improve Society-Science-Policy Interface), the following definitions are de facto used or represent a starting point for the development of definitions in different European countries:

- Austria - refers mostly to the definition provided by the White Paper on Citizen Science for Europe, as a starting point for the development of citizen science practices applied to specific contexts (the Austrian case is discussed in detail below).

- Bosnia and Herzegovina - opted for the development of dedicated definitions, according to focus areas of applications like agriculture, urban management, energy consumption, and disciplines, e.g. social science.

- Czech Republic - uses the ECSA 10 Principles of Citizen Science as a starting point, especially when applying for EU funding, as these are widely acknowledged by the international community and funding bodies.

- Germany - framed citizen science in a strategic national process, as 'scientific activities including or initiated by persons not employed in the scientific system for that purpose'.

- Poland - uses a descriptive definition rather than a normative one, according to Arnstein's 'Ladder of Citizen Participation' (1969) and depending on the different focus activities, e.g. open education, creative commons, open access, and related actors like research and innovation funding, higher and general education institutions, et cetera.

- Slovenia - understands citizen science as the application of participatory approaches into research activities with a focus on policymaking. This implies the active involvement and empowerment of stakeholder communities (scientists, policymakers, and citizens), in the direct development of solutions, projects, policy strategies, and processes of common concern.

- Spain - uses the White Paper on Citizen Science for Europe as a basis, further complemented by specific definitions according to the focus areas or disciplines addressed, e.g. social science.

- Turkey - carries out citizen science as contributory science, whereby citizen science projects are designed by research scientists alone and the members of the public contribute (only) with very specific data.

- United Kingdom - in general, citizen science is seen as a participatory/engagement project, whereby the driver is the resulting benefit to be gained by the participants, both the scientists or the public. As noted in the definition table, in the UK there is a focus on environmental applications, with the UK Environmental Observation Framework leading with its own definition. The main science funder is developing its own strategy for supporting citizen science as part of a wider public engagement strategy.

These examples indicate that there is not a single definition or framework that is used for all cases. We can see that there are different starting points, and a number of criteria for defining citizen science across Europe, each with its own focus according 
to different contexts and objectives. We can expect that these multiple processes will mature over the coming decade, and we will then be able to analyse how these different trajectories influence the practices of citizen science and their impact on different stakeholder communities and their hosting ecosystems.

Even when citizen science is carefully framed, it still can be interpreted in many different ways. To better understand national and cultural differences in interpreting citizen science, we can have a look at an initiative in Austria to identify and define citizen science.

Österreich forscht, the platform for citizen science projects in Austria, was launched in 2014. From the beginning, the platform was committed to guaranteeing the quality of listed projects for the general public. Additionally, project leaders asked for transparent criteria to develop a common baseline for listing citizen science projects. When launching Österreich forscht, the platform coordinators evaluated projects for scientific and participatory aspects. However, these evaluations were not documented in a transparent manner. Therefore, in 2017 the selection process for projects listed on the platform had to be reconsidered.

From 2017 to 2018, so-called Quality Criteria for Citizen Science Projects on Österreich forscht (Heigl et al. 2018) were developed by the Austrian citizen science community in an inter- and transdisciplinary effort to secure the high quality of the projects that are presented on the platform. The process of developing criteria was designed in an open and transparent way. Representatives of 17 institutions collaborated in several personal and online meetings. Feedback loops for project leaders and the general public were conducted. Additionally, the international community was consulted via a workshop at the 2nd International ECSA Conference, held in 2018 in Geneva. This co-creative approach ensured the commitment of the Austrian citizen science community to implementing the criteria in their projects. To support the implementation process, guidelines and tutorial workshops were installed. The 1-year process led to a set of 20 criteria containing sections on scientific rigour, communication, cooperation, open science, transparency, and ethics.

The experiences during the process of developing the criteria motivated working group members to call for a similar process on an international level to strive for an internationally accepted definition of citizen science. This call was published deliberately as opinion in the Proceedings of the National Academy of Sciences of the United States of America (PNAS) in April 2019 (Heigl et al. 2019a). The publication of this opinion caused intensive debates within the international citizen science community on whether or not citizen science needs a definition at a general level and if the Austrian criteria are exclusionary and narrow or enable different forms of citizen science to be included. On a more specific level, this debate showcased how different conceptions and interpretations of citizen science can lead to serious misunderstandings, but also to new insights and positive reactions (Auerbach et al. 2019; Heigl et al. 2019b).

In particular, the topic that was most debated was the exclusionary nature of criteria, which reflected the different backgrounds of the participants in the discussion (and was eventually the catalyst for the development of the definitions in Table 2.1). While some argued that the Austrian criteria were too narrow and 
excluded many projects, others felt that the criteria were very open to different forms of citizen science coming from a wide variety of backgrounds with various goals. Furthermore, the perspectives and positions of the people who take part in citizen science projects were another topic of discussion - whereas some fear that institutional research will take over and define citizen science to the disadvantage of citizen- or community-led research, others want to ensure the scientific integrity of citizen science to build up trust in citizen scientists as well as funders and policies. A consequence of the process in Austria is that the listing of a project on Österreich forscht is perceived as a sign of quality by the Austrian citizen science community and also by the general public. This case shows how different contexts and backgrounds (e.g. country, discipline, non-institutional/institutional) can lead to very different interpretations of citizen science in general and the quality of assessment in particular. The publication of the quality criteria and the opinion piece started a discussion on what citizen science is and who should make this decision at an international level. Such a self-reflective process is very complex and is associated with extensive discussions on the characteristics of citizen science. However, this process is paramount for establishing a robust and approved scientific method that contributes to further increase in scientific knowledge. An emerging outcome of this discussion is the work that is being carried out within the ECSA Working Group on Citizen Science Networks. In this working group, citizen science platform coordinators are collaboratively designing an approach to find common criteria which should be the basis for their respective platforms to decide whether or not to list a project.

In summary, the publication of the criteria for citizen science projects provided an important impetus to intensively address the question of what constitutes a citizen science project and who must/can/is allowed to make this decision. This is an important step towards further developing citizen science and bringing the community closer together.

\section{Definitions in Practice}

So far, we have shown that the discussion about definitions of citizen science demonstrates the importance of reflecting on the boundaries of citizen science and makes it even more obvious that actors in citizen science - including policymakers, funding agencies, scientific communities, and practitioners - need to make transparent what they mean when talking about citizen science.

\section{Definitions in Different Contexts}

Definitions can have different functions, and they need to take into account the respective roles of those who provide a definition and the objectives in establishing 
the definition. The Austrian example showed the necessity of defining quality criteria in the operationalisation of citizen science as a starting point for further discussion. From this example, we have learned that definitions can be perceived as boundaries that are exclusive. Yet, they can also empower actors to create an identity within these boundaries, just as the Austrian citizen science community has done. Additionally, boundaries can also help to formulate transitions. Without definitions or characteristics, citizen science risks becoming an arbitrary term. Actors with an implicitly different understanding or conceptualisation of citizen science might fail in communication and collaboration due to misunderstandings. Ultimately, the citizen science community - including citizen science practitioners, researchers on citizen science, and funding bodies - risks becoming assailable in their work if the term citizen science is not characterised.

When developing, implementing, or adopting citizen science initiatives, a common understanding developed amongst the relevant stakeholders would be enough to identify the influencing factors and preconditions that facilitate the development of citizen science practices in given contexts, even if to reach such common understanding different definitions are used. It is with this spirit that a mapping of definitions against intended objectives, actors, and contexts could help practitioners in identifying and agreeing up front on a common understanding of the initiative to be carried out collectively and the pathway to follow for its development.

More recently, Manzoni et al. (2019) have conveyed the need to investigate opportunities and barriers concerning upscaling and spreading citizen science projects. Along these lines, recent research studies commissioned by the Joint Research Centre of the European Commission (Ideas for a Change, forthcoming ${ }^{2}$ ) identify a few important drivers when developing citizen science initiatives that are even more fundamental when talking about spreading in different contexts and scaling them at different geographical levels. These are, namely, demonstrating the usefulness, value, and benefits with respect to the matter of concern addressed by the initiative, its alignment to legal norms and social values, the ease of being understood, knowledge and resource sharing, and, last but not least, the narrative behind it and the communication material used to promote it.

All in all, we observe that even the definitions used by different European countries are not exclusive but rather complementary. These definitions are a mixture - starting with a more general and open defnition, which are complemented by more specific ones, when contextualisation is needed. From this example, we can take that there are no standalone definitions, but rather multiple combinations depending on the scale of contextualisation needed. The higher the contextualisation, the higher the mixture of definitions and criteria, in order to come to a dedicated one serving that specific context.

Table 2.2 attempts to map the different definitions identified in Table 2.1, by using a matrix based on a stepwise approach: first by grouping the definitions according to the different contexts - political, scientific, societal. These are then

\footnotetext{
${ }^{2}$ https://ec.europa.eu/jrc/communities/en/ecas?destination=node/4341
} 
Table 2.2 Matrix of the function of definitions of citizen science, for different stakeholders and their hosting scientific-socio-economic ecosystems, alongside context objectives

\begin{tabular}{|c|c|c|c|c|}
\hline Context & $\begin{array}{l}\text { Objectives of } \\
\text { the citizen } \\
\text { science } \\
\text { definition }\end{array}$ & Main actors & $\begin{array}{l}\text { Who is expected to } \\
\text { be influenced? }\end{array}$ & $\begin{array}{l}\text { Examples } \\
\text { (numbers refer to } \\
\text { Table 2.1) }\end{array}$ \\
\hline \multirow[t]{4}{*}{ Political } & & $\begin{array}{l}\text { Policy institutions, } \\
\text { policymakers and } \\
\text { officers, interna- } \\
\text { tional organisations, } \\
\text { NGOs }\end{array}$ & $\begin{array}{l}\text { Policymakers and } \\
\text { officers, and, indi- } \\
\text { rectly, society at } \\
\text { large }\end{array}$ & \\
\hline & $\begin{array}{l}\text { Awareness of } \\
\text { policymakers } \\
\text { and consensus } \\
\text { building }\end{array}$ & & & $\begin{array}{l}\text { ECSA definition } \\
\text { (7), German green } \\
\text { paper (30), } \\
\text { Socientize } 2014 \\
(20)\end{array}$ \\
\hline & $\begin{array}{l}\text { Criteria and } \\
\text { legitimation for } \\
\text { funding and } \\
\text { specific } \\
\text { fundraising } \\
\text { schemes }\end{array}$ & & & $\begin{array}{l}\text { ECSA 10 Principles } \\
\text { of Citizen Science } \\
\text { (7), ACSA (5), EU } \\
2019 \text { (23), OECD } \\
2017 \text { (26), US Act } \\
(12)\end{array}$ \\
\hline & $\begin{array}{l}\text { Strategic posi- } \\
\text { tioning and } \\
\text { steering of citi- } \\
\text { zen science } \\
\text { development }\end{array}$ & & & $\begin{array}{l}\text { Citizen Science } \\
\text { Association (8), US } \\
\text { Citizenscience.gov } \\
\text { (13), EU 2016 (21), } \\
E S \& T J(34)\end{array}$ \\
\hline \multirow[t]{4}{*}{ Scientific } & & $\begin{array}{l}\text { RTD institutions, } \\
\text { universities/acade- } \\
\text { mies, individual } \\
\text { researchers, and } \\
\text { amateurs }\end{array}$ & $\begin{array}{l}\text { Scientific communi- } \\
\text { ties and citizen } \\
\text { scientists }\end{array}$ & \\
\hline & $\begin{array}{l}\text { Scientific and } \\
\text { technical } \\
\text { advances, } \\
\text { knowledge and } \\
\text { academic } \\
\text { production }\end{array}$ & & & $\begin{array}{l}\text { US NAS (15), } \\
\text { Nesta (33) }\end{array}$ \\
\hline & $\begin{array}{l}\text { Definition of } \\
\text { research field } \\
\text { and area of } \\
\text { application }\end{array}$ & & & $\begin{array}{l}\text { UNESCO (10), } \\
\text { GEO (9), US } \\
\text { NOAA (16), UK } \\
\text { POST (31) }\end{array}$ \\
\hline & $\begin{array}{l}\text { Self-identifica- } \\
\text { tion as part of a } \\
\text { (research) } \\
\text { community }\end{array}$ & & & $\begin{array}{l}\text { National Geo- } \\
\text { graphic (4), Sci- } \\
\text { ence Europe (27), } \\
\text { SCU (19), OED } \\
\text { (1), Wikipedia (3) }\end{array}$ \\
\hline Societal & & $\begin{array}{l}\text { Local communities, } \\
\text { communities of } \\
\text { practices, local } \\
\text { administrators/ }\end{array}$ & $\begin{array}{l}\text { Citizens, local com- } \\
\text { munities, their } \\
\text { administrators, pro- } \\
\text { ducers/suppliers/ }\end{array}$ & \\
\hline
\end{tabular}


Table 2.2 (continued)

\begin{tabular}{l|l|l|l|l}
\hline Context & $\begin{array}{l}\text { Objectives of } \\
\text { the citizen } \\
\text { science } \\
\text { definition }\end{array}$ & Main actors & $\begin{array}{l}\text { Who is expected to } \\
\text { be influenced? }\end{array}$ & $\begin{array}{l}\text { Examples } \\
\text { (numbers refer to } \\
\text { Table 2.1) }\end{array}$ \\
\hline & $\begin{array}{l}\text { policymakers, local } \\
\text { agencies (cadastres, } \\
\text { energy suppliers, } \\
\text { etc.) }\end{array}$ & $\begin{array}{l}\text { actors in the local } \\
\text { ecosystem }\end{array}$ & \\
\hline & $\begin{array}{l}\text { Address spe- } \\
\text { cific community } \\
\text { challenges }\end{array}$ & & & $\begin{array}{l}\text { US NIH (14) } \\
\text { Awareness and } \\
\text { pundraising } \\
\text { processes }\end{array}$ \\
$\begin{array}{l}\text { Increase of } \\
\text { individuals' } \\
\text { knowledge and } \\
\text { communities' } \\
\text { collective } \\
\text { intelligence }\end{array}$ & $\begin{array}{l}\text { Framing com- } \\
\text { munication sup- } \\
\text { ports and } \\
\text { alliances, net- } \\
\text { working with } \\
\text { other actors }\end{array}$ & & $\begin{array}{l}\text { US NASA (16), US } \\
\text { EPA (15), EU 2017 } \\
\text { (22) }\end{array}$ \\
\hline RAND 2017 (29), \\
UNEP GEO6 (10)
\end{tabular}

used to identify a second level, which is around what the definition is used for (e.g. fundraising, policymaking, awareness, scientific advances, community challenges). We also identify who is expected to be impacted by each group of definitions.

Through this mapping exercise, we can see the types of definitions that can be used according to different objectives, depending on the roles of the different stakeholders that the definition is aimed at and those who are creating it.

The mapping, of course, depends very much on deciding what is the centre of gravity in each definition and matching it with the focus of the specific contexts. As this process is subjective, other interpretations are possible. In addition, the same definition can be mapped against different contexts and objectives, depending on the openness of the definition itself (although here they are linked to one context for the sake of clarity).

Through this initial mapping, we argue that even a limited subset of existing definitions covers all three identified contexts quite well, their descriptions address the objectives of the intended actions within the contexts, and the different stakeholders can identify themselves in terms of roles and values. 


\section{Learning from the Plurality of Definitions}

In this chapter, we have explored the complexity of defining what citizen science is. We have done so by drawing out differences between organisations, countries, understandings, and stages of development of citizen science in a given place.

The diversified use of citizen science definitions clearly indicates that there is not a single definition that is used for all cases. We can see that there are different starting points and number of criteria for defining citizen science around Europe, each with their own focus according to different contexts and objectives.

In this context, the COST survey mentioned above represents a snapshot of different practice developments in European countries. In some countries, citizen science is already a well-known concept, and more or less concrete understandings of citizen science have been developed (e.g. Germany, Austria); in other countries the community is starting to organise and exploring, adjusting, and implementing existing concepts of citizen science in their respective understandings (e.g. Lithuania, Denmark). This can be seen also with the ECSA 10 Principles of Citizen Science, which the Australian Citizen Science Association adjusted for their own needs. Some countries follow a top-down approach, where projects are defined by scientific communities or government agencies; other countries follow bottomup, co-created approaches when a common challenge needs to be addressed by local communities. Also, sometimes the ownership, production, and use of data are the focal points for reaching a common understanding of what citizen science is. Consequently, the definition of citizen science varies from country to country and from community to community.

The development of definitions has no endpoint, and throughout the activities of the COST Action, we observed the continuous development of understandings and definitions. These definitions are instrumental to the purpose of the action and reflect the culture underpinning the specificity of the different contexts in which they are applied. Nevertheless, equally importantly, all of them try to address 'how' and 'to what extent' citizens are involved and participate in science.

It is also important to note that, currently, at international policy level - both in the United Nations system and in the European Commission - citizen science is seen as being part of a wider process called citizen-generated data processes and practices, thereby opening up the possibility of a much wider definition with respect to citizen science going forward. Also, great economic value is being attributed to this emerging source of data, in addition to scientific and social values, as a result of a collective intelligence effort. This development and the higher awareness of the role of information and the precious contribution from society pave the way for the increasing importance of a stronger and more relevant evidence-based policy formulation and implementation. 


\section{Conclusion}

In this chapter, on the background of existing definitions of citizen science, we addressed the question why is it difficult to define citizen science? using theoretical, geographical, practical, and societal approaches. Since citizen science is currently developing so rapidly and the discussions about definitions and criteria are so lively, we have avoided narrowing this down to a single definition. We do not want to anticipate or disrupt the decision-making of the citizen science community with hypothetical recommendations while that community considers whether and how citizen science should be defined. Our hope is that we have invited readers of this chapter and book to reflect on the question of definitions of citizen science from their specific point of view and to recognise the possible intentions, challenges, and potentials of the current situation. However, we would like to emphasise that we expect the discussions to continue in an open, collegial, and fact-based manner, as they have done so far. Having an awareness of the current broad set of definitions in use in citizen science can also help practitioners and policymakers to navigate and support its diversity, as it continues to increase in its scope and scale.

\section{References}

Arnstein, S. R. (1969). A ladder of citizen participation. Journal of the American Institute of Planners, 35(4), 216-224.

Auerbach, J., Barthelmess, E. L., Cavalier, D., Cooper, C. B., Fenyk, H., Haklay, M., et al. (2019). The problem with delineating narrow criteria for citizen science. Proceedings of the National Academy of Sciences, 116(31), 15336-15337.

Balestrini, M., Diez, T., Marshall, P., Gluhak, A., \& Rogers, Y. (2015). IoT community technologies: leaving users to their own devices or orchestration of engagement? EAI Endorsed Transactions on Internet of Things, 1(1). https://doi.org/10.4108/eai.26-10-2015.150601.

Bonn, A., Richter, A., Vohland, K., Pettibone, L., Brandt, M., \& Feldmann, R., et al. (2016). Green paper citizen science strategy 2020 for Germany. Helmholtz Centre for Environmental Research (UFZ), German Centre for integrative Biodiversity Research (iDiv) Halle-Jena-Leipzig, Leipzig, Museum für Naturkunde Berlin, Leibniz Institute for Evolution and Biodiversity Science (MfN), Berlin-Brandenburg Institute of Advanced Biodiversity Research (BBIB), Berlin. https://www.buergerschaffenwissen.de/sites/default/files/assets/dokumente/gewiss_cs_ strategy_englisch.pdf.

Cooper, C. B., \& Lewenstein, B. V. (2016). Two meanings of citizen science. In D. Cavalier \& E. B. Kennedy (Eds.), The rightful place of science: Citizen science (pp. 51-62). Tempe: Consortium for Science, Policy \& Outcomes.

Fishbein, M., \& Ajzen, I. (1975). Belief, attitude, intention and behavior: An introduction to theory and research. Reading: Addison-Wiley Publishing Company.

Haklay, M., Hulbert, J. \& Lea. (2019, November 25). lshanley/CitSciDefinitions: Citizen science definitions (Version v1.2). Zenodo. https://doi.org/10.5281/zenodo.3552753.

Hecker, S., Wicke, N., Haklay, M., \& Bonn, A. (2019). How does policy conceptualise citizen science? A qualitative content analysis of international policy documents. Citizen Science: Theory and Practice, 4, 1. https://doi.org/10.5334/cstp.230.

Heigl, F., Dörler, D., Bartar, P., Brodschneider, R., Cieslinski, M., \& Ernst, M. et al. (2018). Quality criteria for citizen science projects on Österreich forscht. https://osf.io/48j27/. 
Heigl, F., Kieslinger, B., Paul, K. T., Uhlik, J., \& Dörler, D. (2019a). Opinion: Toward an international definition of citizen science. PNAS, 116(17), 8089-8092. https://doi.org/10. 1073/pnas.1903393116.

Heigl, F., Kieslinger, B., Paul, K. T., Uhlik, J., \& Dörler, D. (2019b). Reply to Auerbach et al.: How our opinion piece invites collaboration. Proceedings of the National Academy of Sciences of the United States of America, 116(31), 15338-15338. https://doi.org/10.1073/pnas.1909628116.

Kerson, R. (1989). Lab for the environment. Technology Review, 92(1), 11-12.

Liu, H. Y., \& Kobernus, M. (2017). Citizen science and its role in sustainable development: Status, trends, issues, and opportunities. In L. Ceccaroni \& J. Piera (Eds.), Analyzing the role of citizen science in modern research (pp. 147-167). Hersey: IGI Global.

Manzoni, M., Vohland, K., Schade, S., Tsinaraki, C., \& Dusart, J. (2019). Citizens science and environmental monitoring: Benefits and challenges. http://publications.jrc.ec.europa.eu/reposi tory/handle/JRC117665.

Oxford English Dictionary. (2014). Citizen science. Oxford: Oxford University Press.

Robinson, L. D., Cawthray, J. L., West, S. E., Bonn, A., \& Ansine, J. (2018). Ten principles of citizen science. In S. Hecker, M. Haklay, A. Bowser, Z. Makuch, J. Vogel, \& A. Bonn (Eds.), Citizen science - Innovation in open science, society and policy (pp. 27-40). London: UCL Press.

Rogers, E. M. (2010). Diffusion of innovations. New York: Simon and Schuster.

Serrano Sanz, F., Holocher-Ertl, T., Kieslinger, B., Sanz García, F., \& Silva, C. G. (2014). White paper on citizen science for Europe. Brussels: European Commission. http://www.socientize. $\mathrm{eu} / ? \mathrm{q}=\mathrm{eu} / \mathrm{content/download-socientize-white-paper.} \mathrm{Accessed} 27$ Nov 2018.

Thompson, R. L., Higgins, C. A., \& Howell, J. M. (1991). Personal computing: Toward a conceptual model of utilization. MIS Quarterly, 15(1), 125-143.

Venkatesh, V., \& Davis, F. D. (2000). A theoretical extension of the technology acceptance model: Four longitudinal field studies. Management Science, 46(2), 186-204.

Venkatesh, V., Morris, M. G., Davis, G. B., \& Davis, F. D. (2003). User acceptance of information technology: Toward a unified view. MIS Quarterly, 27(3), 425-478.

Mordechai (Muki) Haklay is a professor of geographic information science at the University College London. He co-directs the Extreme Citizen Science (ExCiteS) research group, dedicated to allowing any community, regardless of literacy, to initiate and run citizen science projects. His research focuses on public access, use, and creation of environmental information, participatory mapping, and citizen science.

Daniel Dörler is a senior scientist at the University of Natural Resources and Life Sciences in Vienna, Austria. He is initiator and coordinator of the Citizen Science Network Austria and its associated platform Österreich forscht. He is the leader of the ECSA working group on citizen science networks and organiser of the annual Austrian Citizen Science Conference.

Florian Heigl is a senior scientist at the University of Natural Resources and Life Sciences in Vienna, Austria. He is initiator and coordinator of the Citizen Science Network Austria and its associated platform Österreich forscht. He is a member of various advisory boards and organiser of the annual Austrian Citizen Science Conference.

Marina Manzoni has been a project and policy officer at the European Commission, since 1991, in information technologies applied to societal challenges. Her interests are in initiatives that benefit both stakeholders and the public while addressing societal needs. She has worked on initiatives at the European level and is on the Citizen Science Team at the EC Joint Research Centre. 
Susanne Hecker studies citizen science as a science communication researcher with a special focus on the science-society-policy interface. She is currently a member of the board of directors of the European Citizen Science Association and a researcher at Helmholtz Centre for Environmental Research - UFZ and the German Centre for Integrative Biodiversity Research (iDiv).

Katrin Vohland supports and investigates knowledge exchange between science, policy, and different publics mainly in the area of biodiversity. She chairs the COST Action CA15212 to explore the added value of citizen science. She was based at the Museum für Naturkunde Berlin and the Leibniz Institute for Evolution and Biodiversity Research. Since June 2020 she is the Director General of the Natural History Museum Vienna, Austria.

Open Access This chapter is licensed under the terms of the Creative Commons Attribution 4.0 International License (http://creativecommons.org/licenses/by/4.0/), which permits use, sharing, adaptation, distribution and reproduction in any medium or format, as long as you give appropriate credit to the original author(s) and the source, provide a link to the Creative Commons license and indicate if changes were made.

The images or other third party material in this chapter are included in the chapter's Creative Commons license, unless indicated otherwise in a credit line to the material. If material is not included in the chapter's Creative Commons license and your intended use is not permitted by statutory regulation or exceeds the permitted use, you will need to obtain permission directly from the copyright holder.

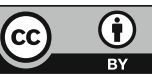

